\title{
HOW TO ANALYSE CHANGE PROCESSES
}

\section{WHY IS THIS IMPORTANT?}

Stories of change are crucial in informing our work as activists. Yet often they are too simplistic Robin Hood-style morality tales that exclude the messiness and accident of real life. Alternatively, they are too complex - full of caveats and impenetrable language - making it hard to read or digest lessons from them. This research guideline suggests an approach to researching and communicating case studies on change in a way that captures a broad range of the actors, power and processes involved.

\section{INTRODUCTION}

Activists often 'stand on the shoulders of giants', drawing inspiration and lessons from the struggles and victories of yesteryear. But how do we extract the lessons from past episodes of change, whether at a large scale - the abolition of slavery to equal marriage legislation - or the countless stories of grassroots change that make up society's understanding of itself and its progress? Based on Oxfam's experience, two books (From Poverty to Power and How Change Happens) and an LSE International Development Masters course on Advocacy, Campaigning and Grassroots Activism, this research guideline sets out some useful tools for analysing processes of change at different levels, with links to various example stories of change, from the Arab Spring to tackling violence against women in South Asia. It explains how to analyse the context and different kinds of power involved in change processes, the interaction of the different players, and how the dynamics of change unfold over time.

\section{IDENTIFY THE COMPONENTS OF CHANGE}

A change process, whether at national or local level, typically involves a combination of four different factors: context, institutions, agents and events (see Figure 1). Disentangling any change process into these components can be a useful first step to understanding what happened. 


\section{CONTEXT}

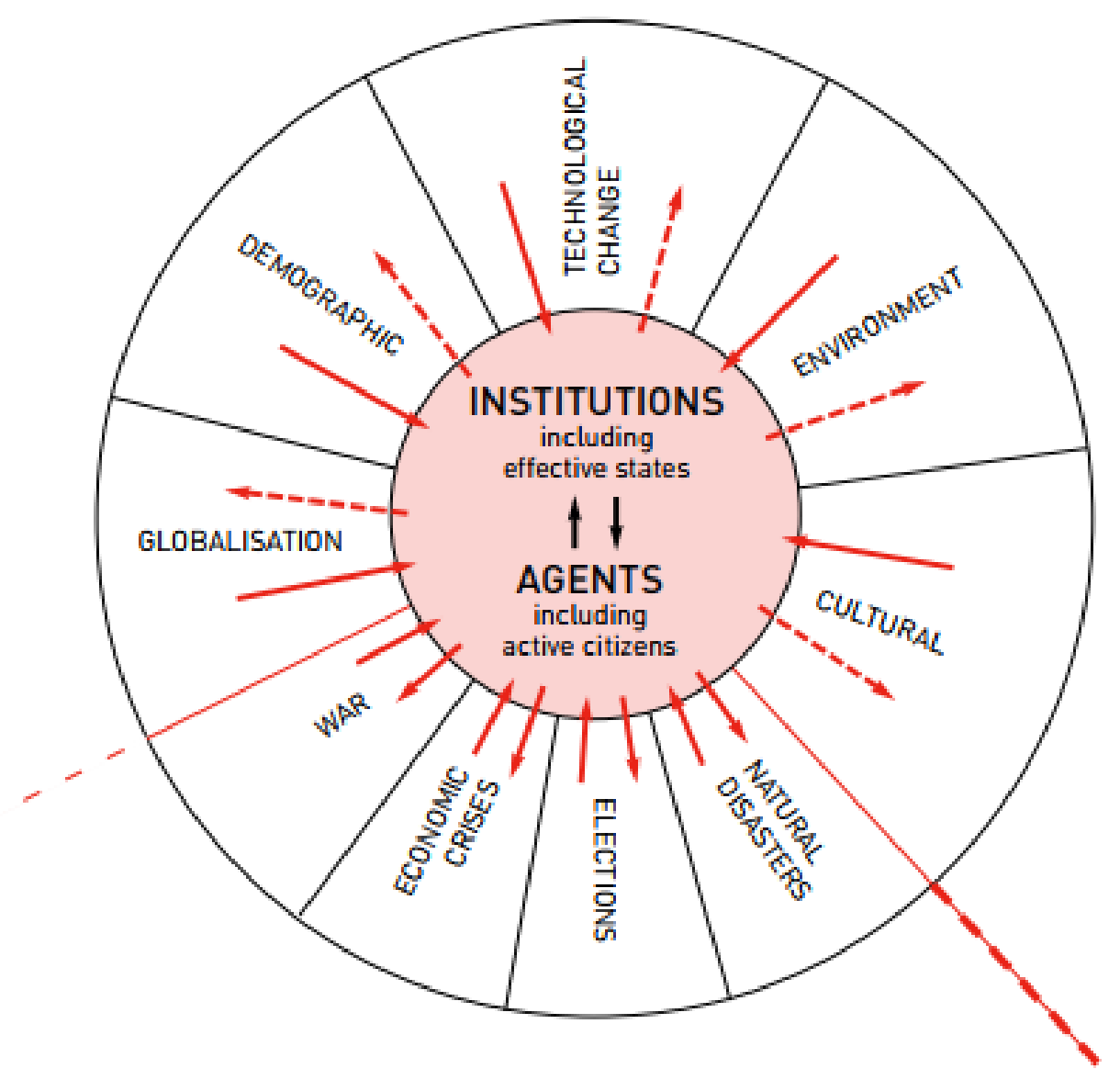

\section{EVENTS}

Source: From Poverty to Power, 2008, Annex A

Context describes the wider environmental factors that are often crucial in driving change, including:

- Demographic change: urbanization, migration, ageing, changing family structures, shifts in the ethnic mix, etc.

- Globalization: constraints and opportunities arising from integration into the global economy.

- Environment: change in the availability of natural resources, climate, etc.

- Technological change: introduction of new technologies such as mobile phones, and the more slow-moving adaptation and dissemination of existing technologies such as electricity or vaccines. 
Institutions: the organizations and rules (both formal and informal) that establish the 'rules of the game' governing the behaviour of agents. These include:

- Social norms shaped by culture, caste and religion: these to a large extent determine the common perceptions of what is right and wrong (by both rulers and ruled), what is socially acceptable, and what is 'normal' in areas such as gender roles, or the acceptability of protest and rebellion. Activists and policy makers talk endlessly about 'debates' precisely because, over the long term, such discussions shape the landscape of politics and power.

- Family structures and norms.

- Formal institutions such as the civil service, the rule of law, democracy, whether inclusionary or exclusionary, autocracy, military rule, etc.

- Public authority: while the aid sector tends to talk in terms of a 'holy trinity' of state, civil society organizations and private sector, in many countries 'public authority' lies in the hands of other players - e.g. traditional authorities, religious leaders, or armed groups.

- The nature of the private sector (formal vs informal, small vs large, national vs foreign).

Agents: organizations and individuals actively involved in promoting or blocking change. Examples include:

- Social movements;

- Political parties;

- Political and business elites, both as drivers and blockers of change;

- Military and police;

- Inspirational leaders;

- Faith leaders.

Events: one-off events that trigger wider change, such as elections, wars, pandemics, civil conflict, natural disasters or economic collapse. At a local level, events such as marches and repression by authorities can be key catalysts to popular organization.

These four factors share some common ground - the boundaries between them are blurred. 'Agents' overlap with 'institutions' when institutions become actively engaged in a change process: the civil service is both an institution and an agent, often being in the driving seat in blocking, or promoting, different kinds of change. Wars are often started deliberately by governments, while revolts and civil wars may stem from armed uprisings by previously excluded groups.

\section{Examples: The Chiquitanos of Bolivia win rights to their lands; Understanding the Egyptian}

\section{Revolution}




\section{BUILD A TIMELINE}

Invest time in creating a timeline of the change process you want to analyse. This takes effort, but provides an indispensable point of reference for subsequent discussions. Think about how all the elements in Figure 1 evolve and interact over time, identifying the 'critical junctures' of change (see section 4).

If your timeline is very full, it can be helpful to separate it out into parallel timelines, for example differentiating between 'big picture' events at national level, and changes that are more specific to the case study, as in this example of the extraordinary success of the cooperative movement in India's dairy sector.

Figure 2: Timeline of Change - Dairy in Gujarat

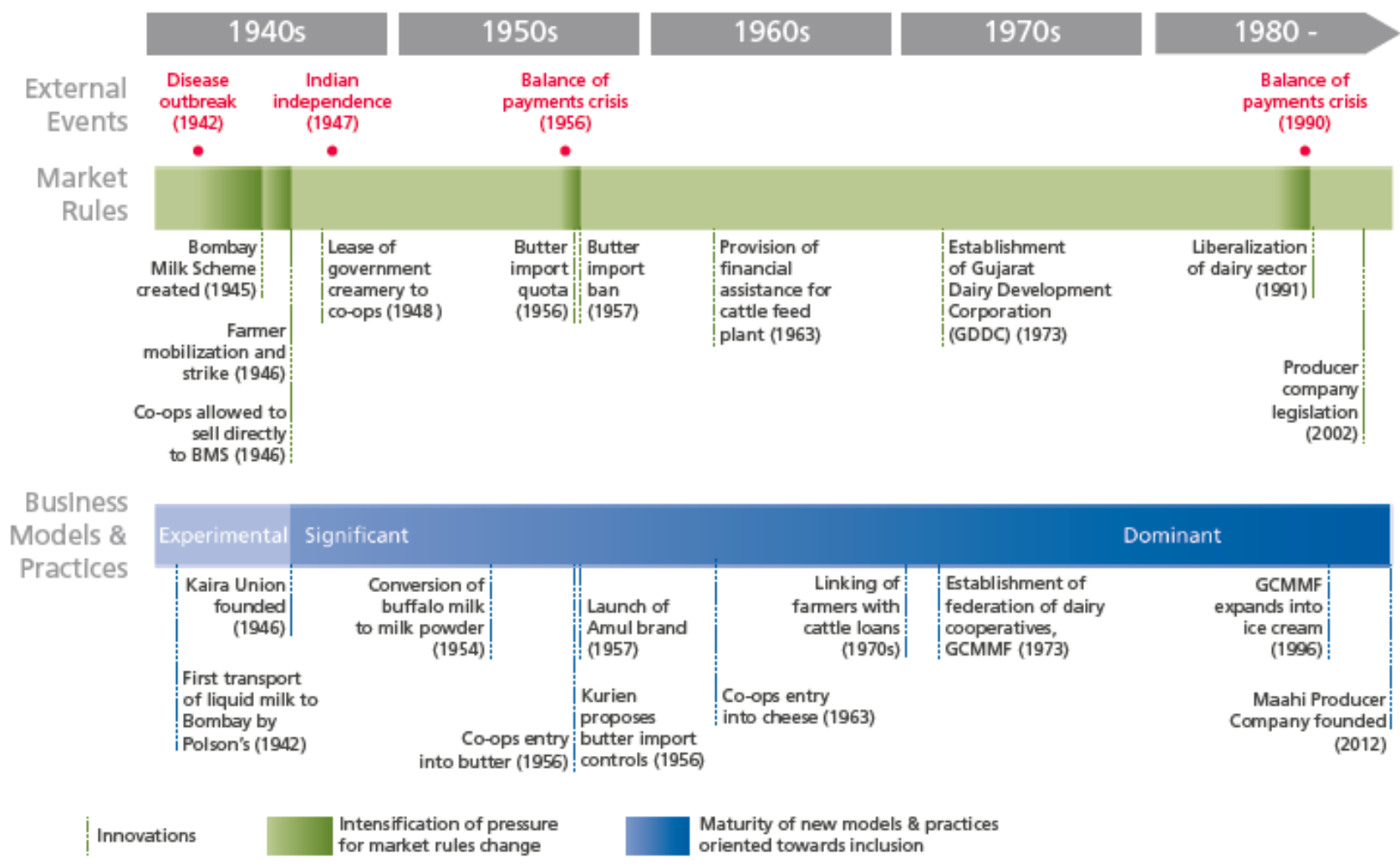

Source: FSG. Shaping Inclusive Markets 


\section{Do A POWER AnALysis And CREATE A STAKEHOLDER MAP}

How agents interact to bring about or frustrate change will depend on their perceptions of their interests, their relative power and their relationships with each other. Building a stakeholder map and conducting a power analysis can be helpful in understanding these interactions.

\section{Power analysis}

Change processes often spring from a renegotiation or redistribution of power in society. Analysing power can thus help us understand particular processes of change. There are many different tools or frameworks to help you do this, but the following are particularly useful:

Visible, invisible and hidden power: While activists often discuss change in terms of the visible world of decision makers and formal authority, considerable power lies elsewhere. This can be in the behind-the-scenes influence of shadowy forces (hidden power) or in the sense of individual or collective agency (invisible power) that can convince citizens to take action, even when the odds seem against them.

Four powers: Oxfam's Jo Rowlands developed a useful typology that distinguishes between:

- Power within: personal self-confidence and a sense of rights and entitlement.

- Power with: collective power, through organization, solidarity and joint action.

- Power to: effective choice, the capability to decide actions and carry them out.

- Power over. the power of hierarchy and domination.

The Rao and Kelleher Framework: Developed by Aruna Rao and David Kelleher for their work on women's rights and empowerment, this is particularly useful for ensuring that stories of change understand and include issues of gender justice and women's rights. 


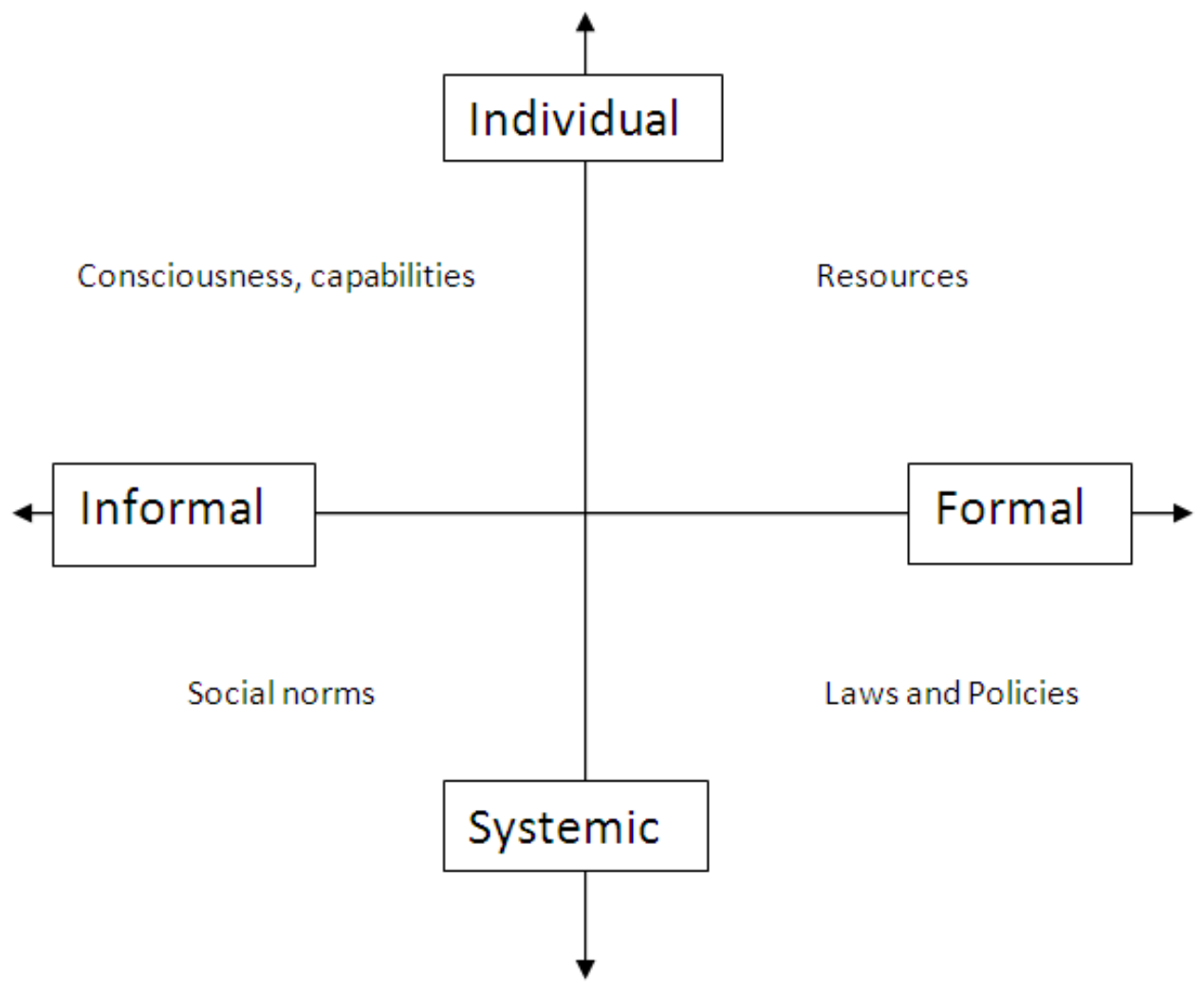

Source: Rao, Sandler, Kelleher and Miller, Gender at Work

Rao and Keller locate change processes according to the nature of the institution in question (on a scale from informal to formal) and the locus of the change being sought (ranging from individual to systemic). They find that activists typically neglect the left-hand side of the framework in their tactics and strategies - i.e. the informal world. By reminding us to look at change in terms of all four quadrants, the framework stresses the interactions between levels (individual, community, formal politics, etc.). For example, in the struggle for women's economic empowerment, moments of individual awareness underpinned changes in both social norms and legislation, culminating in impact on women's position in the workforce - i.e. all four quadrants were involved.

Examples: Changing hearts and minds on violence against women in South Asia; the power of Community Discussion Classes in Nepal. 


\section{Stakeholder mapping}

For any of these different expressions of power, it is then possible to map the different players (e.g. individuals, organizations, countries, alliances) involved in a given change process, and how their positions changed over time. One useful way of doing this is with a chart that shows the degree of influence on the $x$-axis and the level of support/opposition for a given change on the $y$-axis. Figure 3 shows an example of such an analysis, for national positions in the run-up to the 2015 Paris climate change summit.

\section{Figure 3: Power Mapping at the Global Level}

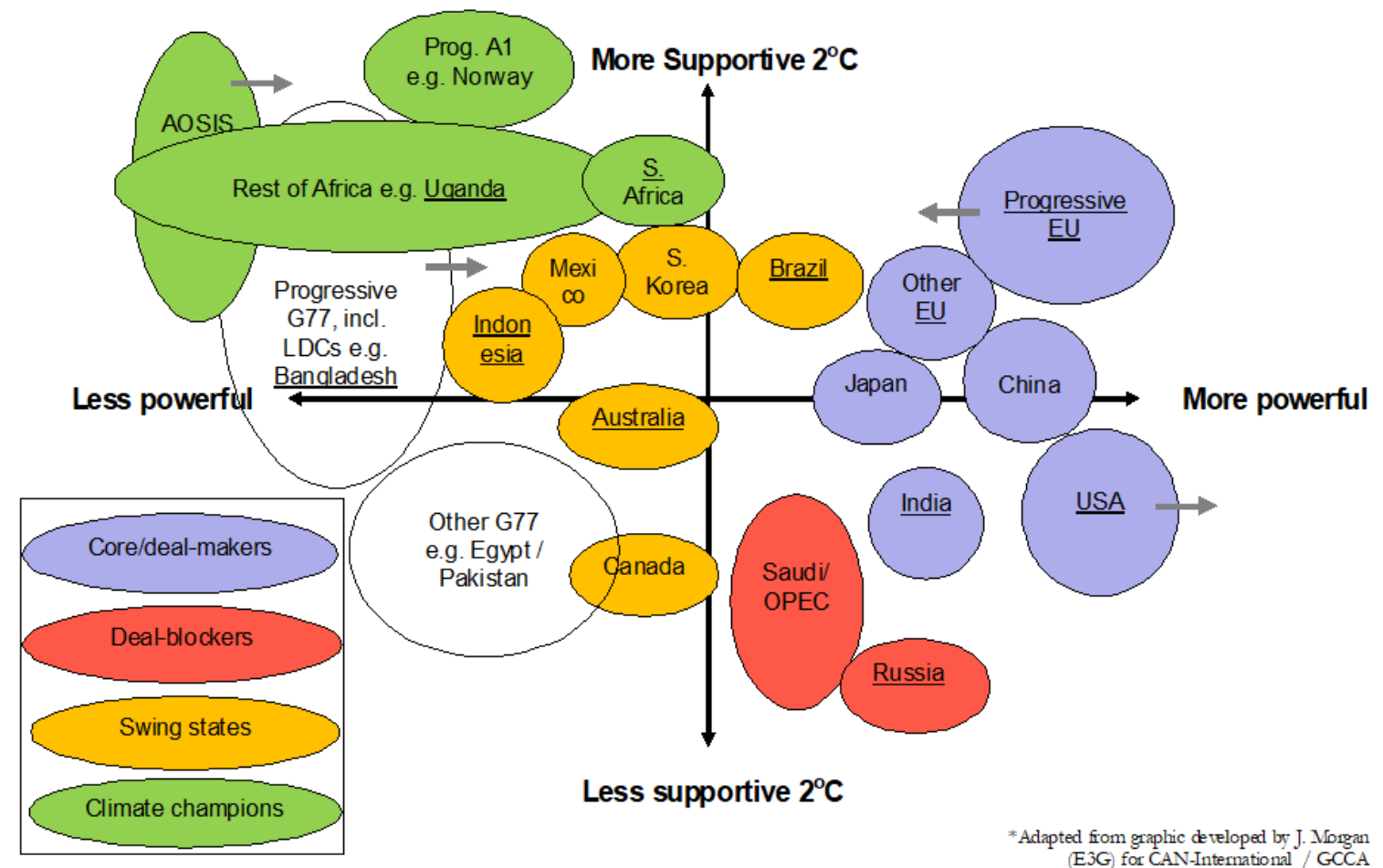

Source: Adapted from graphic developed by J.Morgan (E3G) for CAN-International/GCCA

Mapping players in this way can help identify drivers/blockers, alliances. In combination with the timeline, mapping at different stages, e.g. at the start and end of a particular campaign, can show how these patterns evolved over time.

It is important to do this kind of mapping for all the different kinds of power that emerge during the power analysis (e.g. those in the left-hand quadrants of the Rao and Kelleher Framework) - take care not to slip into a sole focus on the formal power of institutions at this point.

Examples: A village-level power analysis in Tajikistan; How did a global campaign win a UN Arms Trade Treaty? 


\section{CONSIDER The DyNAMICS OF ChANGE}

The components of change combine and interact, creating a complex pathway that involves peaks and troughs of activity and different combinations of context, institutions, agents and events. Change processes are highly complex and unpredictable, but some of the following dynamics are often involved and should be considered in any analysis of how change happened.

Cumulative and sequential progress: Much change is slow and, from close up, may appear inconsequential. Over the longer term, however, changes such as evolving social norms around human rights, or attitudes to violence against women, have profound consequences. Moreover, change processes are sequences: one event or shift leads to another, creating a unique 'pathway of change' that is usually very hard to predict and is not always positive, but which can be analysed in hindsight, especially if a good timeline has been constructed. Often, citizens' organizations interact with states in an iterative fashion, pressing for and responding to reforms.

Critical junctures: Just as in the physics of 'catastrophes', some social and political change is discontinuous, as a series of factors move matters to a sudden 'tipping point'. The process resembles an earthquake - the devastating outcome of an imperceptible build-up in pressure between tectonic plates far below the Earth's surface. Critical junctures can be predictable (elections, deaths of leaders), semi-predictable (climate events) or entirely unpredictable (economic crises, corruption scandals). Try and identify the critical junctures relevant to your change episode, and how they influenced the pathway of change (e.g. political appetite, new alliances, weakening opponents).

Accidents: Unsurprisingly, activists tend to see change as largely intentional - the result of the interplay of deliberate actions by both supporters and opponents of a given change. However, chance and accident often play an unacknowledged role and need to be included in any story of change. For example, a key event that led to the successful outcome of the 2015 Paris climate change negotiations was a terrorist attack in Paris a few weeks earlier. That meant that incoming delegates accepted the need to give the French government a diplomatic victory, yet this is often omitted from accounts of the negotiations.

Change often coalesces around inspirational ideas and individuals: Leaders at all levels can give words and direction to broad discontent or to desire for change. Ideas and words can play a similar catalytic role, which is why campaigners and politicians devote such attention to what are often decried as soundbites and slogans. In your case study, what role was played by ideas and individuals, whether at local level or beyond?

Organization often holds the key to shifting the balance of power: Organization brings safety in numbers and strengthens the ability to influence change. Often the powerful are among the bestorganized groups in society - for example, the business associations and political lobby groups set up by large landowners or firms. However, when poor people get organized, they can transform power relations and trigger deep change.

Demonstration effects: At all levels, people's behaviour is powerfully influenced by their points of reference. The Arab Spring showed how unrest can spread between neighbouring countries. At a local level, change in one community often provides a source of inspiration to neighbours. 
Change through price signals: Pressures for change are often signalled through changes in prices, which themselves are the result of action by governments and companies and the shifting tides of supply and demand. Changes can be sudden, as with the jump in oil prices that triggered global economic chaos in the 1970s, or there can be a gradual shift in relative prices that alters the nature of economic activity, such as the falling cost of mobile technology.

Setbacks: Often the activists/reformers don't get exactly what they want, either due to shooting for the stars in the first place, realpolitik political feasibility, or the need to compromise now for greater change later. Setbacks can occur due to unforeseen challenges, new information arising or backlashes from elites. How did those seeking change cope with setbacks, or even bounce back stronger?

Examples: Success in passing a domestic violence law in Malaw; Using the BP Deepwater Horizon oil spill to create jobs in the US Gulf States; US Equal Marriage

\section{WRITING A STORY OF CHANGE: DOS AND DON'TS}

\begin{tabular}{|l|l|}
\hline Do & Don't \\
\hline $\begin{array}{l}\text { Think about all the expressions of power, not just } \\
\text { the realm of formal/state decision making. }\end{array}$ & $\begin{array}{l}\text { Assume there is a right answer - change processes } \\
\text { always have competing explanations. Historians are } \\
\text { still arguing over the origins of World War One! }\end{array}$ \\
\hline $\begin{array}{l}\text { Identify and discuss critical junctures and accidents } \\
\text { - and what preceded them or made them possible. }\end{array}$ & $\begin{array}{l}\text { Assume that the change was all planned by some } \\
\text { individual or organization. Change is not a project. }\end{array}$ \\
\hline $\begin{array}{l}\text { Make sure to consider change from diverse } \\
\text { perspectives within the story. }\end{array}$ & $\begin{array}{l}\text { Look only to the 'formal' kinds of power (the right- } \\
\text { hand side of Rao and Kelleher). }\end{array}$ \\
\hline $\begin{array}{l}\text { Critically assess and, when necessary, add nuance } \\
\text { to stories that unduly champion/give sole credit to } \\
\text { either individual leaders or institutions. Change } \\
\text { inevitably involves a wide cast of players and } \\
\text { processes. }\end{array}$ & $\begin{array}{l}\text { Don't assume that organizations, such as states or } \\
\text { large companies, speak with one voice - they are } \\
\text { always coalitions rather than monoliths. }\end{array}$ \\
\hline $\begin{array}{l}\text { Get your story of change reviewed by people } \\
\text { involved to get more detail and competing } \\
\text { explanations, and correct errors. }\end{array}$ & $\begin{array}{l}\text { Don't underestimate the cumulative force of long- } \\
\text { term trends. }\end{array}$ \\
\hline $\begin{array}{l}\text { Draw out possible lessons from the case study for } \\
\text { the audience - is it challenging an assumption, } \\
\text { identifying a new tactic or strategy, or offering any } \\
\text { insights for activists? }\end{array}$ & \\
\hline
\end{tabular}




\section{ADDITIONAL RESOURCES}

D. Green, (2008, second edition 2012) From Poverty to Power: How Active Citizens and Effective States Can Change the World, Practical Action/Oxfam

D. Green, From Poverty to Power. https://oxfamblogs.org/fp2p/. This daily blog contains numerous case studies and discussions of change processes, in addition to the links to examples provided above.

D. Green (2016) How Change Happens, OUP. http://how-change-happens.com/

Oxfam (2015), 10 Active Citizenship Case Studies. https://policy-practice.oxfam.org.uk/ourwork/governance-citizenship/active-citizenship-case-studies

D. Green, How to Analyse Stories of Change. Blogpost with examples from LSE Masters

students. https://oxfamblogs.org/fp2p/how-to-analyse-stories-of-change-could-you-help-sharpenup-these-guidelines/

Aruna Rao, Joanne Sandler, David Kelleher and Carol Miller (2016), Gender at Work: Theory and Practice in $21^{\text {st }}$ Century Organizations, Abingdon, Oxford: Routledge Jo Rowlands (1997) Questioning Empowerment: Working With Women in Honduras, Oxfam. https://oxfamilibrary.openrepository.com/bitstream/handle/10546/121185/bk-questioningempowerment-honduras-010197-en. pdf?sequence=5\&isAllowed=y

(c) Oxfam International September 2019

This guideline has been prepared by Oxfam's Research Network for use by development practitioners and researchers, including Oxfam staff and partners. It was written by Duncan Green and edited by Irene Guijt. The author would like to thank Tom Kirk, Ruth Mayne, Joseph Petraglia, Jo Rowlands and all the LSE students that have helped him shape this paper, as well as the numerous activists in developing countries that have informed and helped shape these ideas.

The text may be used free of charge for the purposes of education and research, provided that the source is acknowledged in full. The copyright holder requests that all such use be registered with them for impact assessment purposes. For copying in any other circumstances, or for re-use in other publications, or for translation or adaptation, permission must be secured and a fee may be charged. Email publish@oxfam.org.uk

Oxfam welcomes comments and feedback on its Research Guidelines. If you would like to discuss any aspect of this document, please contact research@oxfam.org.uk. For further information on Oxfam's research and publications, please visit www.oxfam.org.uk/policyandpractice

The information in this publication is correct at the time of going to press.

Published by Oxfam GB for Oxfam International under ISBN 978-1-78748-492-4 in September 2019.

Oxfam GB, Oxfam House, John Smith Drive, Cowley, Oxford, OX4 2JY, UK. Oxfam is a registered charity in England and Wales (no 202918) and Scotland (SC039042).

Oxfam is an international confederation of 20 organizations networked together in more than 90 countries, as part of a global movement for change, to build a future free from the injustice of poverty. 